\title{
INTERFERENSI FONOLOGIS \\ PENUTUR BAHASA MELAYU KUPANG \\ KE DALAM BAHASA INDONESIA DI KOTA KUPANG
}

\author{
Agnes Maria Diana Rafael \\ Sekolah Tinggi Keguruan dan Ilmu Pendidikan \\ Citra Bina Nusantara \\ Jl. Manafe No.17, Kayu Putih, Oebobo, Kupang - NTT \\ Surel/ Ponsel : rafaelagnesmariadiana@gmail.com /+628139816693
}

Submitted: 2018-11-28

Accepted: 2019-01-26

Published: 2019-02-01

\begin{tabular}{ll}
\hline Keywords: & Abstract \\
\hline Interference, & The aims of this study is to identify and describe phonological forms \\
Apokop, & of BMK into BI and the factors that cause the interference of BMK \\
Syncope, & into BI. In accordance with the characteristics studied, this research \\
Bilingual, & is included in descriptive-qualitative research. The population in \\
Creole & this study were 50 urban residents aged 17-45 years who had \\
& different educational and occupational backgrounds. Primary data \\
& in this study was obtained by observing the events in formal places. \\
& Meanwhile the secondary data was obtained through interviews \\
& with the informants. The results of the study found that there was a \\
& disturbance of zero affliction, apokop and syncope in formal speech. \\
& The data is also proved the diphthong sound [aw] is changed to be \\
& a mono single vowel, medium (top) round, semi closed sound [o]. \\
& Furthermore, the factors that cause the BMK interference into BI \\
& are the bilingual factor, the prestige factor and the nativization \\
process (BMK is a creole language).
\end{tabular}

\section{PENDAHULUAN}

Dalam proses berkomunikasi sehari-hari warga masyarakat kota Kupang yang mendiami pulau Timor, Nusa Tenggara Timur (NTT), menggunakan Bahasa Melayu Kupang (selanjutnya disingkat BMK) sebagai lingua franca dalam peristiwa tutur antara sesama warga masyarakat. Sebagai ibu kota provinsi NTT, kota Kupang menjadi tempat bermuaranya masyarakat tutur dari berbagai bahasa, suku, dan budaya sehingga masyarakat kota Kupang adalah masyarakat yang multilingual, multietnis, dan multikultural.

Kota Kupang telah menjadi magnet tersendiri bagi warga di berbagai wilayah di NTT untuk berdatangan. Migrasi mereka membentuk mozaik guyub tutur yang epik dan khas, yaitu guyub tutur BMK. BMK sebenarnya merupakan bagian dari bahasa kreol yang berbasis Melayu. BMK merupakan keturunan langsung dari Bahasa Melayu yang mengalami persentuhan dengan beberapa bahasa, diantaranya adalah Bahasa Belanda, Bahasa Portugis, dan beberapa bahasa daerah di NTT. BMK telah menjadi bahasa ibu bagi masyarakat NTT, teristimewa yang mendiami ibu kota provinsi NTT, yakni kota 
Kupang. Sebagimana bahasa kreol pada umumnya, BMK menunjukan adanya kesamaan khusus dari segi tata bahasa yang mengarah pada teori tata bahasa universal. BMK telah mengalami proses kreolisasi berpuluh-puluh tahun karena merupakan kompilasi dari bahasa dominan yang terpengaruh oleh kosakata-kosakata bawaan dari masyarakat pendatang di kota Kupang.

Oleh karena telah mengalami proses krolisasi, tata bahasanya mengalami perkembangan sehingga menjadi bahasa yang stabil dan terpisah dari bahasa induknya. Penutur BMK terdiri dari berbagai suku, seperti Dawan, Helong, Rote, Sabu, Sumba, Alor, Flores, Jawa, Cina, Bugis, Manado, Ambon, Arab, dan Timor Leste yang tetap mempertahankan identitas kesukuanya masing-masing. Dalam percakapan sehari-hari mereka masih bertutur menggunakan bahasa mereka masing-masing. Namun, seiring dengan perkembangan jaman, generasi selanjutnya yang lahir dan dibesarkan di kota Kupang menjadikan BMK sebagai bahasa ibu dan tidak lagi menguasai (jarang) penggunaan bahasa leluhur mereka.

Tingginya intensitas penggunaan BMK dapat menciptakan peristiwa alternasi atau pemakaian bahasa secara silih berganti antara BMK dan Bahasa Indonesia (selanjutnya disingkat BI) dalam satu kalimat, paragraf, atau wacana. Peristiwa kontak antara BMK yang dipakai dalam konteks percakapan informal dan BI yang dipakai dalam tindak tutur formal, dapat mengakibatkan terjadinya proses interferensi.

Interferensi merupakan fenomena penyimpangan kaidah kebahasaan yang terjadi akibat seseorang menguasai dua bahasa atau lebih. Suwito (1983:54) berpendapat bahwa interferensi sebagai penyimpangan karena unsur yang diserap oleh sebuah bahasa sudah ada padanannya dalam bahasa penyerap, meskipun Suwito (1983:26-27) menekankan bahwa adanya penyimpangan-penyimpangan tidak berarti pengrusakan terhadap suatu bahasa.

Adapun Chaer dan Agustina (2004 : 120) berpendapat bahwa peristiwa interferensi adalah peristiwa digunakannya unsur-unsur bahasa suatu bahasa, maka itu dianggap sebagai suatu kesalahan karena menyimpang dari kaidah atau aturan bahasa yang digunakan. Hortman dan Stork melalui Alwasilah (1985:131) menganggap interferensi sebagai kekeliruan yang disebabkan terbawanya kebiasaan-kebiasaan ujaran bahasa atau dialek bahasa ibu ke dalam bahasa atau dialek kedua.

Bercermin dari pendapat para ahli maka fenomena interferensi bahasa daerah ke dalam bahasa Indonesia menjadi fenomena kebahasaan yang menarik untuk dikaji. Berikut ini dipaparkan beberapa penelitian-penelitian terbaru yang dijadikan bahan perbandingan dan pertimbangan dalam penelitian ini.

Beberapa fenomena interferensi bahasa daerah ke dalam BI yang pernah dikaji oleh beberapa peneliti antara lain yang pertama dilaporkah oleh Masrurah Mokhtar (2000) bahwa bentuk sufiks $-m i$, $-j i$, dan $-p i$ adalah bentuk interferensi afiksasi yang paling produktif dan selalu digunakan ketika para penutur Bahasa Bugis berkomunikasi menggunakan Bahasa Indonesia. Persamaan antara penelitian Mokhtar dan penelitian ini adalah kedua penelitian ini mengkaji interferensi bahasa daerah ke dalam bahasa Indonesia. Perbedaannya adalah penelitian Mokhtar mengkaji interferensi bahasa Bugis menurut kajian morfologis, sedangkan pada penelitian ini mengkaji interferensi BMK menggunakan pisau analisis fonologis.

Selanjutnya, Suindratini, et al. (2013) melaporkan bahwa interferensi bahasa Bali dalam cerita lisan bahasa Indonesia terjadi pada bidang fonologi, yaitu pada saat bunyi diftong pulo 'pulau' dibunyikan. Persamaan kedua penelitian ini adalah mengkaji interferensi bahasa daerah ke dalam Bahasa Indonesia. Perbedaanya kedua penelitian ini terletak pada bidang kajian interferensi yang dipilih. Pada penelitian sebelumnya, para peneliti mengkaji interferensi Bahasa Bali dan Bahasa Asing ke dalam BI, yang meliputi 
interferensi fonologis, morfologis, dan sintaksis. Adapun pada penelitian ini difokuskan penelitiannya pada interferensi fonologis BMK ke dalam BI saja.

Hasil penelitian yang ketiga adalah interferensi leksikal Bahasa Jawa ke dalam Bahasa Indonesia pada karangan siswa kelas V SD Negeri Bukit Raya tahun pelajaran 2016/2017, yang dipaparkan oleh Putri (2017). Berdasarkan hasil penelitian, diketahui terdapat interferensi leksikal bahasa Jawa ke dalam bahasa Indonesia pada karangan siswa kelas V SD Negeri Bukit Raya, tahun pelajaran 2016/2017. Dari data penelitian yang ada ditemukan interferensi leksikal berupa bentuk dasar, bentuk berimbuhan, dan bentuk reduplikasi, dengan komposisi sembilan belas bentuk dasar. Kedua penelitian ini memiliki persamaan, yaitu mendeskripsikan bentuk interferensi bahasa-bahasa daerah ke dalam bahasa Indonesia, serta kedua penelitian ini menggunakan metode penelitian deskriptif kualitatif. Perbedaan kedua penelitian ini adalah sumber data penelitian sebelumnya adalah hasil karangan murid (data tertulis), sedangkan penelitian ini memperoleh sumber data lisan langsung dari narasumber. Teknik yang digunakan untuk memperoleh data ialah teknik tes menulis karangan dan untuk mengetahui penggunaan bahasa siswa, digunakan teknik notes berupa pengisian angket oleh siswa.

Penelitian selanjutnya yang dijadikan pijakan untuk mengkaji penelitian interferensi penutur BMK ke BI, yaitu interferensi Bahasa Galela ke dalam Bahasa Tobelo yang dikaji oleh Martina Kihi Kihi (2015). Hasil penelitiannya mendeskripsikan bentuk-bentuk interferensi fonologis bahasa Galela ke dalam Bahasa Tobelo. Hasil penelitiannya yaitu terjadinya interferensi penambahan fonem dan pengurangan fonem akibat adanya faktorfaktor seperti faktor kedwibahasawan, terbawanya bahasa ibu, letak geografis, dan terjadinya kawin campur. Persamaan antara kedua penelitian ini adalah mendeskripsikan bentuk-bentuk interferensi fonologis bahasa lokal yang ada di Indonesia, sedangkan perbedaannya yaitu hasil pada penelitian tentang interferensi BMK, observasi yang dilakukan tidak saja melalui pangamatan terlibat, pencatatan percakapan, catatan harian, serta kajian kasus saja, tetapi juga melalui observasi partisipatif juga digunakan sebagai alat pengumpul data meskipun data yang diperoleh melalui teknik ini sifatnya sebagai alat untuk mempertegas data yang diperoleh melalui wawancara.

Penelitian yang terakhir yang dijadikan rujukan dalam penelitian ini adalah interferensi Bahasa Indonesia ke dalam Bahasa Jawa oleh Suprihati (2013). Hasil Penelitiannya menemukan bahwa penyimpangan BI yang berwujud kata sebanyak sembilan puluh tiga kata dari tujuh puluh dua kalimat, selanjutnya penyimpangan BI yang berwujud frasa sebanyak dua puluh lima frasa, yang berikutnya adalah penyimpangan BI yang berwujud klausa adalah sebanyak tujuh klausa dari enam kalimat, dan yang terakhir penyimpangan BI yang berwujud baster sebanyak empat puluh sembilan baster dari empat puluh tiga kalimat. Perbedaanya terletak pada bidang kajian linguistik mikro yang diteliti, yaitu pada penelitian terdahulu mengkaji interferensi BI ke dalam Bahasa Jawa pada tataran sintaksis, sedangkan pada penelitian ini, peneliti mengkaji interfernsi BMK ke BI pada tataran fonologis.

Dengan menelaah kajian-kajian kebahasaan yang menjadi rujukan pada penelitian ini, maka disadari bahwa semakin tinggi intensitas kontak suatu bahasa daerah denggan bahasa lainnya pada satu guyub tutur, maka semakin rawan pula terjadinya interferensi antara bahasa-bahasa tersebut. Fenomena itu pula yang terjadi di antara BMK dan BI, misalnya dalam berbahasa Indonesia, ketika seorang mahasiswa penutur asli BMK melaporkan suatu kejadian yang terjadi di depan kampusnya kepada pihak sekuriti kampus, maka dia mengatakan "mahasiswa jurusan Hukum sedang bakalahi di depan kampus." Di sini terjadi interferensi BMK karena penggunaan prefiks $b a$-,yang merupakan salah satu prefiks dalam BMK. 
Fenomena interferensi seperti yang dicontohkan di atas tidak boleh terjadi karena dilihat dari segi kemurnian bahasa, menurut Chaer dan Agustina (2004:125) "nterferensi pada tingkat apapun (fonologi, morfologi, dan sintaksis) merupakan penyakit sebab merusak bahasa." Apalagi, BMK bagi mayoritas masyarakat Nusa Tenggara Timur dipandang sebagai bahasa yang memiliki tingkat prestise yang tinggi dibandingkan dengan bahasa-bahasa daerah di NTT yang lainnya. Setiap masyarakat pendatang di kota Kupang akan berusaha untuk berbicara mengunakan BMK dalam percapakan sehari-hari sehingga dalam kegiatan komunikasi di kota Kupang BMK lebih banyak digunakan daripada BI yang baku.

Berdasarkan asumsi-asumsi dan fenomena-fenomena kebahasaan yang terjadi di kota Kupang, peneliti tertarik untuk mengkaji lebih saksama dengan pisau analisis sosiolinguistik untuk mengidentifikasikan serta mendeskripsikan bentuk-bentuk interferensi fonologis BMK ke dalam BI dan faktor-faktor penyebab terjadinya interferensi BMK ke dalam BI.

\section{METODE}

Penelitian ini menggunakan pendekatan sosiolinguistik, yaitu suatu pendekatan yang mengkaji bahasa dalam kaitannya dengan masyarakat, atau perilaku kelompok, bukan perorangan (Wardhaugh dan Fuller, 2015:2). Sesuai dengan karakter masalah yang ditelaah, penelitian ini termasuk dalam penelitian deskriptif-kualitatif. Metode deskriptif mampu memberikan penjelasan secara sistematis, akurat, dan faktual mengenai data, sifat-sifat dan hubungan fenomena-fenomena yang diteliti dan akhirnya menghasilkan gambaran data yang ilmiah (Djajasudarma, 1993:8).

Populasi dalam penelitian ini adalah 50 warga masyarakat kota Kupang yang berusia 17 - 45 tahun yang memiliki latar belakang pendidikan dan pekerjaan yang berbeda. Pemilihan narasumber didasarkan pada kriteria sebagai berikut: (1) penutur asli BMK (hanya mengusai BMK sebagai bahasa ibu mereka); (2) penduduk asli kota Kupang; (3) berpendidikan SMA hingga perguruan tinggi; dan (4) sehat dan tidak mempunyai cacat wicara. Data primer dalam penelitian ini diperoleh melalui pengamatan peristiwa tutur dalam di tempat-tempat formal dalam sebuah guyub tutur. Adapun data sekunder pada penelitian ini diperoleh melalui proses wawancara mendalam dengan informan guna menemukan jawaban tentang faktor-faktor terjadinya interferensi BMK ke BI dalam suatu peristiwa tutur.

Instrumen atau alat yang dipakai untuk mendapatkan data dalam penelitian ini adalah peneliti sendiri karena peneliti merupakan alat pengumpul data utama (Moleong, 1994:4). Selanjutnya, untuk mendapatkan data tentang faktor-faktor terjadinya interferensi, peneliti menggunakan panduan wawancara. Selain itu, digunakan alat bantu pendukung yang berupa tape recorder (perekam) dan kamera digital. Tape recorder digunakan untuk merekam data hasil wawancara yang dijawab oleh informan. Hasil rekaman kemudian ditranskripsikan melalui pencatatan sehingga memudahkan untuk mengelompokkan data.

Untuk mengumpulkan data dilakukan dengan beberapa cara. Cara pertama adalah dengan observasi yang dilakukan dengan pangamatan terlibat tentang percakapan formal di tempat kerja dan di lingkungan pendidikan (misalnya di sekolah dan kampus) menggunakan BMK. Dengan pengamatan terlibat dapat digunakan sebagai data yang dapat menguatkan bukti interferensi fonologis BMK ke BI oleh penutur asli BMK di kota Kupang. Selanjutnya, dilakukan pencatatan percakapan, catatan harian, serta kajian kasus. Proses wawancara dilakukan untuk menggali informasi yang berkaitan dengan faktorfaktor penyebab interferensi. Proses wawancara.

Adapun teknik analisis data dalam penelitian ini adalah analisis data kualitatif terhadap data-data yang berhasil dikumpulkan dan diperoleh di lapangan. Data yang diperoleh 
dianalisis secara kualitatif melalui tiga tahapan, yaitu klasifikasi data, interpretasi data, dan analisis deskriptif yang disajikan dalam bentuk narasi.

Tahapan selanjutnya setelah data dianalisis adalah penyajian hasil analisis data. Dalam pelaksanaannya hasil analisis data dapat disajikan secara informal dan formal (Sudaryanto, 1993:43). Penelitian ini menggunakan metode pemaparan hasil analisis data informal karena hanya memakai perumusan dengan kata-kata biasa dan yang terpenting ialah menggunakan kata-kata yang mudah dimengerti.

\section{HASIL DAN PEMBAHASAN}

Pada bab ini akan ditampilkan data yang berupa interferensi bahasa Indonesia oleh penutur asli BMK melalui berbagai tabel berikut ini.

Tabel 1 Identifikasi Data Interferensi

\begin{tabular}{|c|c|c|}
\hline No. & $\begin{array}{l}\text { Bahasa Indonesia yang mengalami } \\
\text { interferensi dari Bahasa Melayu } \\
\text { Kupang }\end{array}$ & BAHASA INDONESIA BAKU \\
\hline 1 & $\begin{array}{l}\text { Anak-anak mari sebaiknya jika kalian } \\
\text { bateman jangan saling memilih } \\
\text { teman. }\end{array}$ & $\begin{array}{l}\text { Anak-anak sebaiknya jika kalian berteman } \\
\text { janganlah saling memilih teman. }\end{array}$ \\
\hline 2 & Kau mau pi mana? & Mau pergi kemana dirimu? \\
\hline 3 & $\begin{array}{l}\text { Apapakah kamu mau makan deng } \\
\text { ikan goreng? }\end{array}$ & Apakah kamu mau makan dengan ikan goreng? \\
\hline 4 & Indonesia mardeka. & Indonesia merdeka \\
\hline 5 & Sepatunya talempar ke udara. & Sepatunya terlempar ke udara \\
\hline 6 & Cukup jangan ditambah lai. & Cukup jangan ditambah lagi \\
\hline 7 & $\begin{array}{l}\text { Apa yang kamu lakukan itu terlalu } \\
\text { lebe. }\end{array}$ & Apa yang kamu lakukan itu berlebihan \\
\hline 8 & Ibu, saya $s u$ selesaikan tugas saya. & Ibu, saya sudah selesai mengerjakan tugas saya. \\
\hline 9 & $\begin{array}{l}\text { Ibu bapa mari silahkan ditambah dolu } \\
\text { makanannya! }\end{array}$ & Bapak dan ibu silahkan ditambah lagi makananya. \\
\hline 10 & Maaf, saya sudah tidak ada uang lai & Maaf, saya sudah tidak ada uang lagi. \\
\hline 11 & Lama-lama kami akan murka sandia & Lama kelamaan kami akan marah dengan dirinya \\
\hline 12 & $\begin{array}{l}\text { Ini kabon kami punya, jadi kami mo } \\
\text { tanam tanaman ijo-ijo saja }\end{array}$ & $\begin{array}{l}\text { Kabun ini kami punya, jadi kami mau menanan } \\
\text { sayuran hijau saja. }\end{array}$ \\
\hline 13 & $\begin{array}{l}\text { Anak-anak kici berlarian di halaman } \\
\text { belakang ruma. }\end{array}$ & $\begin{array}{l}\text { Anak-anak kecil berlarian di halaman belakang } \\
\text { rumah. }\end{array}$ \\
\hline 14 & Ini ju mereka punya kendaraan & Ini juga adalah kendaraan mereka \\
\hline 15 & Parmisi pak sa mo lewat! & Permisi pak saya mau lewat \\
\hline 16 & $\begin{array}{l}\text { Selamat pagi taman-taman, saat ini } \\
\text { saya mau memperkenalkan sodara } \\
\text { saya. }\end{array}$ & $\begin{array}{l}\text { Selamat pagi teman-teman, saat ini saya mau } \\
\text { memperkenalkan saudara saya. }\end{array}$ \\
\hline 17 & $\begin{array}{l}\text { Tolong dalam bagaul kamu jangan } \\
\text { iko-iko kawan lain. }\end{array}$ & $\begin{array}{l}\text { Tolong dalam bergaul kamu jangan ikut-ikutan } \\
\text { teman yang lain. }\end{array}$ \\
\hline 18 & $\begin{array}{l}\text { Tolong bacakan carita yang kalian } \\
\text { buat di depan kelas. }\end{array}$ & $\begin{array}{l}\text { Tolong bacakan cerita yang kalian buat didepan } \\
\text { kelas }\end{array}$ \\
\hline 19 & $\begin{array}{l}\text { Mama saya tidak bisa tidur tadi } \\
\text { malam, saya merasa galisa sampe } \\
\text { pagi. }\end{array}$ & $\begin{array}{l}\text { Mama saya tidak bisa tidur tadi malam. Saya merasa } \\
\text { gelisah sampai pagi. }\end{array}$ \\
\hline 20 & $\begin{array}{l}\text { Pakailah helem ini agar kau bisa } \\
\text { melindungi kapala kau dari benturan } \\
\text { keras! }\end{array}$ & $\begin{array}{l}\text { Pakailah helem ini agar kamu bisa melindungi } \\
\text { kepala kamu dari benturan keras! }\end{array}$ \\
\hline 21 & Capat selesaikan kau pung tugas. & Cepat selesaikan tugas kalian! \\
\hline
\end{tabular}




\begin{tabular}{|c|c|c|}
\hline 22 & $\begin{array}{l}\text { Sebelum dikumpulkan di meja saya } \\
\text { tolong pariksa kembali tugas kalian. }\end{array}$ & $\begin{array}{l}\text { Sebelum dikumpulkan di meja saya, tolong periksa } \\
\text { kembali tugas kalian. }\end{array}$ \\
\hline 23 & $\begin{array}{l}\text { Semalam pancuri dua orang masuk ke } \\
\text { rumah kami. }\end{array}$ & Semalam dua orang pencuri masuk ke rumah kami. \\
\hline 24 & $\begin{array}{l}\text { Ana saya yang } s u \text { besar sekarang su } \\
\text { kuliah di UNDANA }\end{array}$ & $\begin{array}{l}\text { Anak saya yang sulung sedang kuliah di UNDANA } \\
\text { sekarang. }\end{array}$ \\
\hline 24 & $\begin{array}{l}\text { Papagi hari mereka sudah pi laut } \\
\text { untuk mencari ikan. }\end{array}$ & $\begin{array}{l}\text { Pagi dini harir mereka sudah pergi ke laut untuk } \\
\text { mencari ikan. }\end{array}$ \\
\hline 25 & $\begin{array}{l}\text { Ketika kalian sampe di kampus tolong } \\
\text { hubungi saya. }\end{array}$ & $\begin{array}{l}\text { Ketika kalian sudah sampai di kampus tolong } \\
\text { hubungi saya. }\end{array}$ \\
\hline 26 & Mengapa kaulia-lia saya & Mengapa kamu terus memandang saya? \\
\hline 27 & $\begin{array}{l}\text { Tolong lihat pengumuman yang ada } \\
\text { supaya kalian tidak masok salah kelas }\end{array}$ & $\begin{array}{l}\text { Tolong baca pengumunan yang ada supaya kalian } \\
\text { tidak masuk ke kelas yang salah. }\end{array}$ \\
\hline 28 & $\begin{array}{l}\text { Apakah kamu sanang pergi ke pantai } \\
\text { Lasiana kemarin sore? }\end{array}$ & $\begin{array}{l}\text { Apakah kamu senang pergi ke pantai Lasiana } \\
\text { kemarin sore. }\end{array}$ \\
\hline 29 & $\begin{array}{l}\text { Jangan katawa besar-besar di ruang } \\
\text { guru. }\end{array}$ & $\begin{array}{l}\text { Jangan tertawa dengan suara yang besar di ruang } \\
\text { guru! }\end{array}$ \\
\hline 30 & $\begin{array}{l}\text { Karena kau datang terlambat, } \\
\text { makanya kau tidak dapa oleh-oleh } \\
\text { dari Lukas. }\end{array}$ & $\begin{array}{l}\text { Karena kamu datang terlambat makanya kamu tidak } \\
\text { dapat oleh-oleh dari Lukas. }\end{array}$ \\
\hline 31 & Kami sudah makan abis & Kami sudah selesai makan. \\
\hline 32 & $\begin{array}{l}\text { Karena udara sangat panas di Kupang, } \\
\text { jadi saya sering merasa aus }\end{array}$ & $\begin{array}{l}\text { Karena udara di Kupang sangat panas, sehingga saya } \\
\text { sering merasa haus. }\end{array}$ \\
\hline 33 & Dia suka memakai baju warna itam & Dia suka memakai baju berwarna hitam \\
\hline 34 & $\begin{array}{l}\text { Kota Kupang memiliki curah ujan } \\
\text { yang rendah. }\end{array}$ & Kota Kupang memiliki curuh hujan yang rendah \\
\hline 35 & Kau seperti manusia utan saja & Kamu seperti orang hutan saja. \\
\hline 36 & $\begin{array}{l}\text { Kamu jang makan di luar karena } s u \\
\text { mulai malam }\end{array}$ & $\begin{array}{l}\text { Kamu jangan makan di luar karena sudah mulai } \\
\text { malam. }\end{array}$ \\
\hline 37 & $\begin{array}{l}\text { Mama bilang mama taku dudu } \\
\text { sendirian di dalam ruma }\end{array}$ & $\begin{array}{l}\text { Mama bilang mama takut duduk sendirian di luar } \\
\text { rumah. }\end{array}$ \\
\hline 38 & $\begin{array}{l}\text { Kalo kamu tidak naekkalas maka } \\
\text { kamu sebaiknya pindah ke sekolah } \\
\text { swasta sa }\end{array}$ & $\begin{array}{l}\text { Kalau kamu tidak naik kelas maka sebaiknya kamu } \\
\text { pindah ke sekolah swasta saja. }\end{array}$ \\
\hline 39 & $\begin{array}{l}\text { Debt kolektor sering datang tagi uang } \\
\text { ke kantornya }\end{array}$ & $\begin{array}{l}\text { Debt kolektor sering datang menagih uang ke } \\
\text { kantornya. }\end{array}$ \\
\hline 40 & $\begin{array}{l}\text { Saya tidak bisa iko kamu ke Soe } \\
\text { karena saya ada urusan laen }\end{array}$ & $\begin{array}{l}\text { Saya tidak bisa ikut kamu ke Soe karena saya ada } \\
\text { urusan lain }\end{array}$ \\
\hline 41 & $\begin{array}{l}\text { Waktu om saya berlibur ke Bali } \\
\text { dengan sodara saya yang laen, } \\
\text { mereka berkunjung ke pante Kuta }\end{array}$ & $\begin{array}{l}\text { Waktu om saya berlibur ke Bali dengan saudara saya } \\
\text { yang lain, mereka berkunjung juga ke pantai Kuta. }\end{array}$ \\
\hline 42 & Kau bodok kayak kerbo & Kamu bodoh seperti kerbau \\
\hline 43 & Tolong jangan terlalu rame di kelas ini & Tolong jangan terlalu ramai di kelas ini \\
\hline 44 & $\begin{array}{l}\text { Pulo Komodo adalah pulo yang } \\
\text { sangat indah }\end{array}$ & Pulau Komodo adalah pulau yang sangat indah \\
\hline 45 & $\begin{array}{l}\text { Sapa yang tumpahkan aer di lantai ini } \\
\text { ? Cepat ambil kaen lap! }\end{array}$ & $\begin{array}{l}\text { Siapa yang tumpahkan air di lantai ini? Cepat } \\
\text { ambilkan kain lap! }\end{array}$ \\
\hline 46 & $\begin{array}{l}\text { Kami balajar TOEFL di pusat bahasa } \\
\text { UNDANA }\end{array}$ & Kami belajar TOEFL di pusat bahasa UNDANA. \\
\hline 47 & $\begin{array}{l}\text { Bapak saya membeli tana kebun } \\
\text { untuk kami }\end{array}$ & Bapak saya membeli tanah kebun untuk kami \\
\hline 48 & Adisaya lulus ujian masok UMPTN & Adik saya lulus ujian masuk UMPTN \\
\hline 49 & $\begin{array}{l}\text { Panggilkan petugas keberihan untuk } \\
\text { kasih bersihlante ini dulu }\end{array}$ & $\begin{array}{l}\text { Panggilkan petugas kebersihan untuk bersihkan } \\
\text { lantai ini dulu }\end{array}$ \\
\hline 50 & Mama mo pergi cuci baju di sunge & Mama mau pergi cuci baju di sungai \\
\hline
\end{tabular}


Dari data tersebut muncul penghilangan bunyi. Penghilangan bunyi yang dimaksud adalah penghilangan bunyi fonemis (zeroisasi) BI sebagai akibat interferensi BMK. Proses zeroisasi adalah penghilangan bunyi fonemis sebagai akibat upaya penghematan atau ekonomisasi pengucapan (Muslich, 2010). Proses zeroisasi dalam BI sebagai akibat adanya interferensi BMK ke BI terdiri atas:

Tabel 2 Data Zeroisasi Aferesis

\begin{tabular}{|c|c|c|c|}
\hline \multirow{3}{*}{$\begin{array}{l}\text { Penanggalan/ } \\
\text { Fonem }\end{array}$} & & \multicolumn{2}{|c|}{ Data Penghilangan/Penanggalan } \\
\hline & \multicolumn{3}{|c|}{ Satu Fonem di Awal Kata } \\
\hline & $\begin{array}{l}\text { Bahasa } \\
\text { Indonesia }\end{array}$ & BMK & Hasil Interferensi \\
\hline [h] & [hitam] & [itam] & (33)[itam] \\
\hline [h] & [hijau] & [ijo] & (12)[ijo] \\
\hline [h] & [haus] & [aus] & (32) [aus] \\
\hline [h] & [hutan] & [utan] & (35)[utan] \\
\hline [h] & [hujan] & [ujan] & $(34)[$ ujan] \\
\hline [h] & [habis] & [abis] & (31) [abis] \\
\hline
\end{tabular}

Zeroisasi afaresis yakni penghilangan atau penanggalan satu atau lebih fonem pada awal kata. Berdasarkan data pada Tabel 2, maka proses zeroisasi aferisis BI dapat dilihat pada Tabel 1, data (31) [abis] , (32) [aus], (33) [itam], (34) [ujan], dan (35) [utan]. Berdasarkan data yang dianalisis zeroisasi afarisis BI terjadi pada kata-kata yang diawali oleh bunyi konsonan geseran laringal $[\mathrm{h}]$.

Tabel 3. Data Zeroisasi Apokop

\begin{tabular}{|c|c|c|c|}
\hline \multirow[t]{2}{*}{$\begin{array}{l}\text { Penanggalan/ } \\
\text { Fonem }\end{array}$} & \multicolumn{3}{|c|}{$\begin{array}{l}\text { Data Penghilangan/Penanggalan } \\
\text { Satu Fonem atau Lebih di Akhir Kata }\end{array}$} \\
\hline & $\begin{array}{l}\text { Bahasa } \\
\text { Indonesia }\end{array}$ & BMK & Hasil Interferensi \\
\hline$[e],[r],[g]$ & [pergi] & {$[p i]$} & (9) [pi] \\
\hline \multirow[t]{2}{*}[a]{,$[\eta]$} & [deyan] & [den] & (3) $[\mathrm{de \eta}]$ \\
\hline & [lagi] & [lai] & (6) [lai] \\
\hline$[i],[h]$ & [lebih] & [lebe] & (7) [lebe] \\
\hline$[u],[d],[h]$ & [sudah] & {$[s u]$} & (8) $[s u]$ \\
\hline$[h]$ & [rumah] & [ruma] & (13) [ruma] \\
\hline$[g],[a]$ & [juga] & {$[j u]$} & (14) $[j u]$ \\
\hline$[u],[t]$ & [ikut] & [iko] & (17) [iko] \\
\hline$[h]$ & [gelisah] & [galisa] & (19) [galisa] \\
\hline$[\tilde{\eta}],[a]$ & [puĩa] & [puฑ] & (21) [рuך] \\
\hline$[t]$ & [liat] & [lia] & (26) $[\mathrm{lia}]$ \\
\hline$[t]$ & [dapat] & [dapa] & (30) $[$ dapa] \\
\hline$[t]$ & [takut] & [taku] & (37) [taku] \\
\hline$[t]$ & [tagih] & [tagi] & (39)[tagi] \\
\hline$[k]$ & [duduk] & {$[d u d u]$} & (37) [dudu] \\
\hline$[h]$ & [rumah] & [ruma] & (37) [ruma] \\
\hline$[t]$ & [tanah] & [tana] & (47) $[\tan a]$ \\
\hline$[k]$ & [adik] & [adi] & (48)[adi] \\
\hline
\end{tabular}


Ada zeronisasi apokop, yakni penghilangan atau penanggalan satu atau lebih fonem pada akhir kata. Berdasarkan data pada Tabel 3, proses zeroisasi apokop dapat dilihat pada data(9) [pi], (3) [dej], (6) [lai], (7) [lebe], (8) [su], (13) [ruma], (14) [ju], (17) [iko-iko], (19) [galisa], (21) [puy], (26) [lia], (30) [dapa], (37) [taku], [dudu], [ruma], (39) [tagi], (47) [tana], (48) [adi].

Data (9) dalam BI dilafalkan [pergi], akan tetapi ketika terjadi interferensi BMK ke BI, maka kata [pergi] mengalami penanggalan tiga fonem di tengah kata, yaitu fonem vokal depan [e], konsonan hambat apikoalveolar [r], dan konsonan hambat dorsovelar [g], sehingga bunyi kata tersebut berubah menjadi [pi]. Data (3) [dey], dalam BI dilafalkan [deyan], namun ketika terjadi proses interferensi BMK ke BI maka kata [deyan] mengalami penanggalan dua fonem diakhir kata, yaitu fonem vokal belakang [a] dan fonem konsonan akhir nasal apikoalveolar [n], maka hasil dari interferensi tersebut menghasilkan bunyi baru yang diakhiri dengan bunyi nasal dorso-velar [ $\mathrm{n}]$ sehingga kata [deyan] dalam BI dilafalkan dengan bunyi [den]. Data (6) [lai], dalam BI dilafalkan [lagi], ketika terjadi penanggalan satu fonem di tengah kata, yakni fonem konsonan letup dorsovelar[g], maka kata [lagi] berubah bunyi menjadi bunyi [lai]. Data (7) [lebe], dalam BI dilafalkan [lebih], ketika terjadi penanggalan dua fonem diakhir kata, yaitu fonem vokal depan [i] dan fonem konsonan nasal dorso-velar [h]. Kedua fonem tersebut berubah menjadi fonem depan [e], maka bunyi [lagi] dalam BI berubah bunyi menjadi bunyi [lai]. Data (8) [su],dalam BI dilafalkan [sudah], ketika terjadi penanggalan tiga fonem yakni fonem konsonan hambat letup apiko-dental [d], vokal tengah [a], dan konsonan dorsovelar [h], maka bunyi [sudah] dalam BI berubah menjadi bunyi [su]. Data (13) [ruma], dalam BI dilafalkan dengan bunyi [rumah], ketika terjadi penanggalan satu fonem akhir yakni fonem konsonan dorso-velar [h], maka bunyi [rumah] dalam BI berubah menjadi bunyi [ruma]. Data (14) [ju], dalam BI dilafalkan dengan bunyi [juga], saat terjadi penanggalan dua fonem di akhir kata yakni fonem konsonan letup dorso-velar [g] dan fonem vokal tengah [a], maka bunyi [juga] dalam BI berubah menjadi bunyi [ju]. Data [17) [iko-iko] dalam BI dilafalkan sebagai (ikut-ikut), saat terjadi interferensi maka bunyi tersebut mengalami penanggalan dua fonem yaitu fonemvokal belakang $[\mathrm{u}]$ dan fonem konsonan hambat letup apiko-dental $[\mathrm{t}]$. Adapun kedua fonem tersebut diganti dengan fonem vokal belakang [o] sehingga bunyi (ikut-ikut) dalam BI berubah menjadi bunyi [iko-iko]. Data (19) [galisa], dalam BI dilafalkan sebagai bunyi [gelisah], saat terjadi interfernsi bunyi tersebut dilafalkan sebagai bunyi [galisa]. Berdasarkan data terebut, terjadi penanggalan satu fonem di bagian akhir, yakni fonem konsonan nasal dorso-velar [h] dan terjadi substitusi fonem vokal pertama pada kata tersebut yaitu vokal depan [e] menjadi vokal tengah [a], sehingga bunyi [gelisah] dalam BI berubah menjadi bunyi [galisa]. Data (21) [puy], dalam BI dilafalkan sebagai [puña], saat terjadi interferensi, maka bunyi tersebut mengalami penanggalan dua fonem akhir yakni fonem konsonan nasal medio-palatal $[\tilde{\eta}]$ dan fonem vokal tengah [a]. Selanjutnya, kedua fonem tersbut diganti dengan bunyi nasal dorso-velar [ $\mathrm{n}$ ] sehingga bunyi [puña] dalam BI berubah menjadi bunyi [puy]. Data (26) [lia], dalam BI dilafalkan [lihat]. Saat terjadi interfernsi, maka bunyi tersebut mengalami penanggalan tiga fonem. Satu fonem berada di posisi tengah kata yaitu fonem geseran laringal [h]; fonem lainnya adalah fonem vokal tengah [a], dan satu fonem lainnya berada tepat di posisi akhir kata yakni fonem konsonan hambat letup apiko-dental [t] sehingga bunyi [lihat] dalam BI mengalami interfernesi BMK menjadi bunyi [lia]. Data (30) [dapa] dalam BI dilafalkan [dapat]. Saat terjadi interferensi, maka bunyi tersebut mengalami penangalan satu fonem konsonan hambat letup apikodental yakni fonem [t] sehingga bunyi [dapat] dalam BI, mengalami penangggalan bunyi menjadi bunyi [dapa] yang merupakan proses interfeernsi BMK. 
Data (37) [taku], dalam BI dilafalkan [takut]. Saat terjadi interferensi, maka bunyi tersebut mengalami penangalan satu fonem konsonan hambat letup apiko-dental yakni fonem [t] sehingga bunyi yang seharusnya [takut] dalam BI, namun karena adanya penangggalan bunyi yang merupakan proses interferensi BMK, maka dilafalkan bunyi [taku]. Data (37) [dudu], dalam BI dilafalkan sebagai [duduk]. Saat terjadi interferensi, maka bunyi tersebut mengalami penanggalan satu fonem konsonan letup dorso-velar [k] sehingga bunyi yang seharusnya [duduk], berubah menjadi bunyi [dudu]. Data (37) [ruma], dalam BI dilafalkan sebagai [rumah]. Saat terjadi interferensi, maka bunyi tersebut mengalami penanggalan satu fonem geseran laringal $[\mathrm{h}]$, sehingga bunyi yang seharusnya [rumah] dilafalkan sebagai [ruma]. Data (39) [tagi], dalam BI dilafalkan sebagai [tagih]. Saat terjadi interferensi maka bunyi tersebut mengalami penanggalan satu fonem geseran laringal $[\mathrm{h}$ ], sehingga bunyi yang seharusnya [tagih] dilafalkan sebagai [tagi]. Data (47) [tana], dalam BI dilafalkan sebagai [tanah]. Saat terjadi interferensi, maka bunyi tersebut mengalami penanggalan satu fonem geseran laringal $[\mathrm{h}]$ sehingga bunyi yang seharusnya [tagih] dilafalkan sebagai [tana]. Data (48) [adi] dalam BI dilafalkan sebagai [adik]. Saat terjadi interfernsi maka bunyi tersebut mengalami penanggalan satu fonem konsonan letup dorso-velar [k] sehingga bunyi yang seharusnya [adik] berubah menjadi bunyi [adi] karena adanya interferensi BMK ke BI.

Zeroisasi sinkop adalah penghilangan atau penanggalan satu atau lebih fonem pada tengah kata. Berdasarkan data yang ada pada Tabel 4, maka proses zeroisasi sinkop dapat dilihat pada data (1) [bateman], (4) [mardeka], (5) [talempar], (9) [dolu], (12) [kabon], (18) [carita], (19) [galisa], (20) [kapala], (21) [pariksa], (22) [pancuri], (27) [masok], (28) [sanang], dan data (29) [katawa].

Berdasarkan data di atas, penanggalan sekaligus penggantian fonem ditengah kata paling banyak terjadi di fonem vokal pertama dalam kata-kata BI. Misalnya data (1) [bateman], dalam BI dibunyikan [berteman], namun yang dilafalkan bunyi [bateman]. Vokal depan madya [e] mengalami perubahan menjadi vokal tengah rendah [a] sehingga bunyi kata [berteman] berubah menjadi bunyi [bateman], selain itu pula terjadi pelesapan bunyi konsonan getar apiko-alveolar [r], setelah bunyi vokal rendah [a]. Perubahan bunyi vokal pertama [e] menjadi bunyi vokal [a] terjadi hampir pada seluruh kata yang memiliki bunyi vokal pertama [e] setelah konsonan pertama yang posisinya diawal sebuah kata. Misalnya pada data (4) [mardeka], (5) [talempar], (12) [kabon], 18 [carita], (19) [galisa], (20) [kapala], (21) [pariksa], (22) [pancuri], (28) [sanang] dan data (30) [katawa] sehingga berdasarkan data yang dianalisis, maka terjadi interferensi bunyi vokal pertama yang merupakan vokal madya depan [e] menjadi vokal depan rendah [a]. 
Tabel 4. Data Zeroisasi Sinkop

\begin{tabular}{|c|c|c|c|}
\hline \multirow[t]{2}{*}{$\begin{array}{l}\text { Penanggalan dan perubah } \\
\text { Fonem }\end{array}$} & \multicolumn{3}{|c|}{ Data Penghilangan/Penanggalan } \\
\hline & Bahasa Indonesia & BMK & Hasil Interferensi \\
\hline$[e],[r]$ & [berteman] & [bateman] & (1)[bateman] \\
\hline$[e]$ & [merdeka] & [mardeka] & (4) [mardeka] \\
\hline$[e],[r]$ & [terlempar] & [talempar] & (5) [talempar] \\
\hline$[a],[h],[u]$ & [dahulu] & [dolu] & (9) $[$ dolu $]$ \\
\hline [e] & [cerita] & [carita] & (18) [carita] \\
\hline$[e]$ & [kebun] & [kabon] & (12) [kabon] \\
\hline$[e]$ & [kepala] & [kapala] & (20) [kapala] \\
\hline$[e]$ & [periksa] & [pariksa] & (21) [pariksa] \\
\hline [e] & [pencuri] & [pancuri] & (22) [pancuri] \\
\hline [u] & [masuk] & [masok] & (27) [masok] \\
\hline [e] & [senang] & [sanang] & (28) [sanang] \\
\hline$[e]$ & [ketawa] & [katawa] & (29) [katawa] \\
\hline
\end{tabular}

Perubahan dua bunyi vokal atau vokal rangkap (diftong) dalam BI menjadi vokal tunggal (monoftong) dalam BMK sebagai akibat proses interferensi fonologis. Menurut Chear (2009:104-105) monoftongisasi adalah proses perubahan dua buah vokal atau gugus vokal menjadi sebuah vokal. Tabel 4 menunjukan bahwa data (41) [sodara], data (44) [pulo], data (42) [kerbo], dan data (43) [mo] dalam BI seharusnya dilafalkan [sawdara], [pulaw], [kerbaw], dan [maw]. Akan tetapi, saat terjadi interferensi maka bunyi diftong [aw] pada kata-kata tersebut mengalami monoftonggisasi menjadi satu vokal tunggal yaitu vokal belakang, sedang (atas) bundar, semi tertutup [o] sehingga bunyi yang dihasilkan akibat adanya interferensi BMK, yaitu [sodara], [pulo], [kerbo] dan [mo]. Data (43) [rame], (41) [pante], (49) [lante], dan (50) [suye], dalam BI seharusnya dilafalkan [ramai], [pantai], [lantai], dan [suyai]. Namun demikian, saat terjadi interferensi, sedang (atas), tidak bundar, semi tertutup, yaitu vokal [e].

Tabel 5. Data Proses Monoftonggisasi

\begin{tabular}{|c|c|c|c|}
\hline \multirow[t]{2}{*}{$\begin{array}{l}\text { Perubahan } \\
\text { bunyi vokal }\end{array}$} & \multicolumn{3}{|c|}{$\begin{array}{l}\text { Data Peerubahan Dua Bunyi Vokal atau } \\
\text { Vokal Rangkap } \\
\text { Menjadi Vokal Tunggal }\end{array}$} \\
\hline & Bahasa Indonesia & BMK & Hasil Interferensi \\
\hline$[a w]$ & [sawdara] & [sodara] & (41) [sodara] \\
\hline [aw] & [pulaw] & [pulo] & (44) [pulo] \\
\hline [aw] & [kerbaw] & [kerbo] & (42) [kerbo] \\
\hline [aw] & [maw] & [mo] & ( 12) $[\mathrm{mo}]$ \\
\hline [ai] & [ramai] & [ramè] & (43) [ramè] \\
\hline [ai] & [pantai] & [pantè] & (41) [pantè] \\
\hline [ai] & [lantai] & [lantè] & (49) [lantè] \\
\hline [ai] & [suyai] & [suyè] & (50) [sujè] \\
\hline
\end{tabular}

Perubahan dua bunyi vokal atau vokal rangkap (diftong) dalam BI menjadi vokal tunggal (monoftong) dalam BMK sebagai akibat proses interferensi fonologis. Menurut Chear (2009:104-105) monoftongisasi adalah proses perubahan dua buah vokal atau gugus vokal menjadi sebuah vokal. Tabel 4 menunjukan bahwa data (41) [sodara], data 
(44) [pulo], data (42) [kerbo], dan data (43) [mo] dalam BI seharusnya dilafalkan [sawdara], [pulaw], [kerbaw], dan [maw]. Namun, saat terjadi interferensi maka bunyi diftong [aw] pada kata-kata tersebut mengalami monoftonggisasi menjadi satu vokal tunggal, yaitu vokal belakang, sedang (atas) bundar, semi tertutup [o] sehingga bunyi yang dihasilkan akibat adanya interferensi BMK yaitu [sodara], [pulo], [kerbo] dan [mo]. Data (43) [rame], (41) [pante], (49) [lante], dan (50) [suye], dalam BI seharusnya dilafalkan [ramai], [pantai], [lantai], dan [suyai]. Namun, saat terjadi interferensi, sedang (atas), tidak bundar, dan semi tertutup, yaitu vokal [e].

Faktor-faktor penyebab terjadinya interferensi BMK ke dalam BI meliputi: (1) Faktor kedwibahasaan bahasa penutur. Penutur BMK di kota Kupang berasal dari berbagai suku, budaya, dan bahasa daerah yang berbeda-beda. BMK telah dijadikan sebagai lingua franca untuk menjembatani perbedaan bahasa yang beraneke ragam dalam satu peristiwa tutur. Tingginya intensitas penggunaan BMK menyebabkan para penutur BMK terbiasa berbicara dengan penutur lainya menggunakan BMK baik di dunia kerja formal maupun informal. Akibatnya interferensi fonologis BMK ke dalam BI tidak dapat dihindari. Pengamatan peneliti sepanjang penelitian menunjukan bahwa sangat sedikit interaksi antara rekan-rekan kerja atau teman-teman sejawat baik di lingkungan kerja di sektor swasta maupun di pemerintahan yang berkomunikasi sehari-hari menggunakan BI. Mereka cenderung memilih berkomunikasi sehari-hari menggunakan BMK dari pada menggunakan BI. BMK telah menjadi bahasa pemersatu antara warga masyarakat di kota Kupang yang berasal dari berbagai suku, budaya, dan bahasa yang berbeda.

Prestise BMK dibandingkan dengan bahasa-bahasa daerah lainnya. Di kota Kupang BMK adalah bahasa yang memiliki prestise yang tinggi. Sebagai contohnya adalah para mahasiswa yang berasal dari kabupaten-kabupaten di NTT, yang sedang berkuliah di kota Kupang, merasa bangga ketika berbicara dengan lancar menggunakan BMK. Selain itu, mayoritas warga masyarakat yang menetap di kota Kupang selama berpuluh-puluh tahun lamanya telah melahirkan anak-anak yang memiliki bahasa pertama mereka adalah BMK. Oleh sebab itu, semakin banyaknya jumlah penutur asli (native speaker) BMK, maka semakin tinggi pula prestise BMK dibandingkan bahasa-bahasa lainya di kota Kupang.

Faktor Kreolisasi BMK adalah selain BMK adalah bahasa yang memiliki prestise tertinggi, yang menjadi salah satu faktor terjadinya interferensi BMK ke BI adalah karena proses kreolisasi BMK. BMK telah menjadi mother language sebagian besar anak-anak yang lahir di kota Kupang berpuluh-puluh tahun yang lalu. Berdasarkan identitas para informan, maka dari 50 informan, terdapat 23 informan yang memperoleh BMK sebagai bahasa pertama mereka. Oleh sebab itu, para informan lebih mengusai BMK dibandingkan dengan BI.

\section{SIMPULAN}

Berdasarkan analisis data diperoleh simpulan bahwa interferensi BMK ke dalam BI yang dilakukan oleh penutur asli BMK mengakibatkan terjadinya proses zeroisasi atau pengilangan bunyi fonemis sebagai akibat upaya penghematan atau ekonomisasi pengucapan. Proses zeroisasi tersebut meliputi zeroisasi afaresis, zeroisasi apokop dan zeroisasi sinkop. Selain terdapatnya proses zeroisasi, akibat lain dari terjadinya proses interferensi BMK ke BI, yaitu terjadinya proses monoftongisasi.

Selanjutnya, faktor-faktor penyebab interferensi BMK ke dalam BI meliputi faktor kedwibahasaan bahasa penutur dan faktor prestise BMK dibandingkan dengan bahasabahasa lokal lainnya yang terdapat di provinsi NTT.

Interferensi BMK ke dalam BI yang dilakukan oleh penutur asli BMK di kota Kupang seharusnya dihindari kerena interferensi merupakan salah satu gejala penyimpangan bahasa, dalam hal ini adalah penyimpangan norma Bahasa Indonesia. Jika interferensi ini 
dibiarkan, para penutur BMK akan mengalami kesulitan dalam menguasai BI dengan baik, benar, dan akurat. Hasil penelitian ini diharapkan dapat membuka wawasan para penutur BMK tentang bahaya interferensi BMK ke dalam BI sehingga para penutur BMK dapat mengantisipasi dan mencegah terjadinya interferensi BMK ke dalam BI.

\section{DAFTAR PUSTAKA}

Alwasilah, C. (1985). Sosiologi Bahasa. Bandung. Angkasa Bandung.

Chaer, A. dan Leonie, A.(1995). Sosiolinguistik Perkenalan Awal. Jakarta: PT. Rineka Cipta.

Djajasudarma, F. T.(1993). Metode Linguistik Ancangan Metode Penelitian dan Kajian. Bandung: PT.Eresco.

Kihi-Kihi, M.(2017). Interferensi Bahasa Galela ke dalam Bahasa Tobelo. Skripsi. Fakultas Sastra Universitas Sam Ratulangi. Manado.

Mokhtar, M.(2000). Interferensi Morfologis Penutur Bahasa Bugis dalam Berbahasa Indonesia. Humaniora. 12(2), 219-224.

Moeleong, L. J.(1994). Metode Penelitian Kualitatif. Bandung: Remaja Rosta Karya

Putri, N. E. (2017). Interferensi Leksikal Bahasa Jawa ke dalam Bahasa Indonesia pada Karangan Siswa Kelas V SD Negeri Bukit Raya Tahun Pelajaran 2016/2017. Skripsi. Pendidikan Bahasa dan Seni FKIP Universitas Lampung. Bandar Lampung.

Sudaryanto. (1993). Metode dan Aneka Teknik Analisis Bahasa (Pengantar Penelitian Wahana Kebudayaan Secara Linguistis). Yogyakarta: Duta Wacana University Press.

Suindratini, dkk. (2013). Interferensi Bahasa Bali dan Bahasa Asing dalam Cerita Lisan Bahasa Indonesia Kelas VII Siswa SMP Negeri 10 Denpasar. e-Journal Program Pascasarjana Universitas Pendidikan Ganesha Program Studi Pendidikan Bahasa dan Sastra Indonesia, 2.

Suwito.(1983). Sosiolinguistik Teori dan Problema. Surakarta: Henary Offset Solo.

Wardhaugh, F.(2015). An Introduction to Sociolinguistics. (Seventh Edition). Wiley Blackwell. 